\title{
Geochemical characteristics of soil gas in the Yanhuai basin, northern China*
}

\author{
Ying $\mathrm{Li}^{1} \quad$ Jianguo Du ${ }^{1, \uparrow}$ Fukuan Wang ${ }^{2} \quad$ Xiaocheng Zhou ${ }^{1}$ \\ Xiaodong Pan ${ }^{3}$ and Ruqing $\mathrm{Wei}^{4}$ \\ ${ }^{1}$ Institute of Earthquake Science, China Earthquake Administration, Beijing 100036, China \\ ${ }^{2}$ Inner Mongolia Corporation Ltd. of Geologic Engineering, Hohhot 010051, China \\ ${ }^{3}$ Earthquake Administration of Jilin Province, Changchun 130022, China \\ ${ }^{4}$ Liaocheng Seismology Hydro-chemistry Test Station, Liaocheng 252000, China
}

\begin{abstract}
The geochemical backgrounds and origins of soil gases in the Yanhuai basin are discussed based on the regional seismogeological data and concentrations of $\mathrm{Rn}, \mathrm{Hg}, \mathrm{CO}_{2}, \mathrm{H}_{2}, \mathrm{He}$ and $\mathrm{CH}_{4}$ in soil gas measured at 422 investigating sites in field during September to October 2007. The geochemical background values of $\mathrm{Rn}, \mathrm{Hg}, \mathrm{CO}_{2}, \mathrm{H}_{2}, \mathrm{He}$ and $\mathrm{CH}_{4}$ are $(8105.8 \pm 5937.4) \mathrm{Bq} / \mathrm{m}^{3},(9.7 \pm 5.8) \mathrm{ng} / \mathrm{m}^{3},(395.9 \pm 35.3) \times 10^{-6},(4.0 \pm 2.3) \times 10^{-6},(15.9 \pm 10.4) \times 10^{-6}$ and $(12.7 \pm 8.1) \times 10^{-6}$, respectively. The geochemical backgrounds of the soil gases are higher in the eastern part of the Yanhuai basin. The main factors affecting the gasgeochemical backgrounds are gaseous origins, structure of the crust, faults, stratum and microbe activity. The higher values of gasgeochemical backgrounds in the eastern part are attributed to the existence of low-velocity zones in the upper crust, stronger tectonic activity and more contributions of $\mathrm{Hg}$ and He derived from the deep-earth and Rn originated from granite, corresponding to stronger seismic activity. The results can be applied to identifying seismic precursor from monitoring data of gases in the studied area.
\end{abstract}

Key words: soil gas; geochemistry; fault activity; Yanhuai basin

CLC number: X141 Document code: A

\section{Introduction}

The Yanhuai basin, a seismically active area (Xu et al, 2002; Liu et al, 1997) located in the northwestern part of Zhangbo seismic belt, is an important monitoring area of seismic hazard. Four historical earthquakes $(M>6)$ and 163 earthquakes with magnitudes larger than 2.0 occurred between 1970 and 2004 (Zhu et al, 2006), which indicates that seismic activity is high in the Yanhuai basin. It is primary and important for earthquake prediction to monitor and identify seismic precursors, which is based on determination of background of each monitoring item. There exists good correlation between the concentration distributions of gases $(\mathrm{Rn}, \mathrm{Hg}$, $\mathrm{CO}_{2}, \mathrm{H}_{2}, \mathrm{He}, \mathrm{CH}_{4}$ and so on) in the soil and the stress and strain in the crust (Wang et al, 1990), therefore underground gases usually show precursory signals be-

\footnotetext{
* Received 15 May 2008; accepted in revised form 9 September 2008; published 10 February 2009.

- Corresponding author. e-mail: jianguodu@hotmail.com
}

fore and after earthquake occurrence. From the earthquake monitoring works of last 40 years in China, it can be concluded that the underground gases are good indicators for earthquakes (Wang et al, 1990; Du et al, 1997; Du and Kang, (2000a, b; Liu et al, 2006) and predominant seismic precursors (Wan et al, 2002; Chiodini et al, 2004; Du, 2005; Du et al, 2008). With over-exploitation of groundwater, which leads to sharp decline of groundwater level, gasgeochemical measurement was more and more used in seismic monitoring other than hydrogeochemical measurement.

However, the gasgeochemical monitoring in the Yanhuai basin now are mainly conducted in a few of monitoring stations, and few multi-index monitoring results of gasgeochemistry are reported (Cao, 2005; Xu, 2006). It has been shown that the abundances of gas components in soil can be easily affected by some factors, such as atmospheric permutation, biogenic process, mantle degassing, radiogenic production, rock alteration origins (Zhang et al, 1988; 1990; Ciotoli et al, 2007). 
Therefore, it is difficult to identify seismic precursor using measurements of a gas component and to characterize geochemical backgrounds in the whole study area. It is emphasized that increasing amounts of sampling sits and monitoring objects is vital for earthquake monitoring (Ciotoli et al, 2005, 2007; Baubron et al, 2002; Zhang and Sanderson, 1996; Igarashi and Wakita, 1995). Up to now, rare result of soil gas surveying in large-scale sampling and multi-index monitoring has been published. It is necessary to conduct soil gas survey of $\mathrm{Rn}, \mathrm{Hg}, \mathrm{CH}_{4}, \mathrm{CO}_{2}, \mathrm{He}$ and $\mathrm{H}_{2}$ in the Yanhuai ba$\sin$. The results help better understanding of the soil gas geochemical background and recognizing seismic precursors in the Yanhuai basin.

\section{Field exploration}

The concentrations of $\mathrm{Rn}, \mathrm{Hg}, \mathrm{CH}_{4}, \mathrm{CO}_{2}$, $\mathrm{He}$ and $\mathrm{H}_{2}$ were measured in the field at 422 sampling sites in the Yanhuai basin (about $2200 \mathrm{~km}^{2}$ ) from 20 September to 30 October, 2007. The distance between every two surveying sites is averagely about $2 \mathrm{~km}$. A Teflon probe sampler was employed for sample collection and measurement, which was inserted into the hole (diameter, 30 $\mathrm{mm}$ and $80 \mathrm{~mm}$ in depth) obtained by driving a steel stick into the ground. Rn was analyzed by an HDC-B Radon Detector with a calibration error of $0.3 \%$ (Zhou et al, 2007). The measuring chamber ( $2 \mathrm{~L}$ volume) of the instrument was cleaned at first by soil gas, then a film sampler was inserted into the chamber in which soil gas was pumped up to a pressure of $1.5 \times 10^{5} \mathrm{~Pa}$. After $3 \mathrm{~min}$ sampling, the film sampler was transported into the instrument for testing. The concentration of $\mathrm{Hg}$ was measured with a RA-915+ Zeeman Effect Mercury Instrument that was connected to the Teflon probe sampler. The analyzing data can be read out in site under the gas sample mode of the instrument with a calibration error of $3 \%$. Other gases $\left(\mathrm{CH}_{4}, \mathrm{CO}_{2}\right.$, $\mathrm{He}$ and $\left.\mathrm{H}_{2}\right)$ were analyzed by a gas chromatography (Agilent 3000) with a calibration error of 5\%. In sampling a $30 \mathrm{ml}$ soil gas sample collected with a glass syringe was injected directly into the gas chromatography for measuring. The procedure can effectively prevent the contamination of air. The errors for the measuring data are 7\% for $\mathrm{Rn}, 6.5 \%$ for $\mathrm{Hg}$ and $5 \%$ for $\mathrm{CH}_{4}, \mathrm{CO}_{2}$, $\mathrm{He}$ and $\mathrm{H}_{2}$, respectively.

\section{Results and discussion}

The minimum, maximum and average values of measured gaseous components are listed in Table 1.
Table 1 Gas geochemical data of the Yanhuai basin

\begin{tabular}{|c|c|c|c|c|c|}
\hline & Min & $\operatorname{Max}$ & Mean & $\begin{array}{l}\text { Standard } \\
\text { deviation }\end{array}$ & Remark \\
\hline $\mathrm{Hg} / \mathrm{ng} \cdot \mathrm{m}^{-3}$ & 1.0 & 54.0 & 9.7 & 5.8 & Sediments are \\
\hline $\mathrm{CH}_{4}, 10^{-6}$ & 0.0 & 52.3 & 12.7 & 8.1 & mainly loess soil \\
\hline $\mathrm{He}, 10^{-6}$ & 0.1 & 175.7 & 15.9 & 10.4 & in Holocene and \\
\hline $\mathrm{Rn}, \mathrm{Bq} / \mathrm{m}^{3}$ & 1302.0 & 57812.0 & 8105.8 & 5937.4 & upper Pleisto- \\
\hline $\mathrm{CO}_{2}, 10^{-6}$ & 331.5 & 572.6 & 395.9 & 35.3 & $\begin{array}{c}\text { cene series in } \\
\text { Quaternary }\end{array}$ \\
\hline $\mathrm{H}_{2}, 10^{-6}$ & 0.0 & 73.2 & 4.0 & 2.3 & system \\
\hline
\end{tabular}

\subsection{Mercury}

In the Yanhuai basin, the average concentration of $\mathrm{Hg}$ in soil gas is $9.7 \mathrm{ng} / \mathrm{m}^{3}$, the minimum and maximum values are $1.0 \mathrm{ng} / \mathrm{m}^{3}$ and $54.0 \mathrm{ng} / \mathrm{m}^{3}$, respectively. The Yanhuai basin is divided by the north boundary fault of Yanfan basin into two sub-basins, the Huaizhuo basin and Yanfan bain, in the western and eastern parts, respectively (Figure 1). The contour map (Figure 2) shows that mercury concentration in the western part is lower than that in the eastern part. The number of high $\left(\geq 20 \mathrm{ng} / \mathrm{m}^{3}\right)$ and low $\left(\leq 5 \mathrm{ng} / \mathrm{m}^{3}\right) \mathrm{Hg}$ concentration sites accounts for $4 \%$ and $8 \%$ of total sampling sites, respectively. Statistic results show that the $\mathrm{Hg}$ concentration data do not correspond to the models of normal distribution and logarithmic distribution, indicating multiple sources of $\mathrm{Hg}$ and influencing factors of mercury. In addition, the factor analysis results (Table 2) show that the factor 1 is dominated by mercury, which means $\mathrm{Hg}$ is relative independent. Vapor pressure of mercury is high at normal temperature. Vapor pressure and evaporation rate of mercury are increased sharply with increasing temperature, resulting in its strong penetrating ability and escaping into air easily (Wei and Shen, 1995). On the contrary, mercury can be recycled back into soil through atmospheric precipitation process (Zhou et al, 2007). Mercury in the soil may be mainly originated from the deep crust and partially from Quaternary sediments, and migrate upwards to the Earth surface through faults and fractures. In the Yanhuai basin, $\mathrm{Hg}$ concentrations sites spatially distribute inhomogeneously, that may be caused by variations in sediment thickness, crustal thickness and adsorption ability, underground temperature and pressure gradient, as well as the movements of thermal fluids (Che et al, 2001). Obvious inhomogeneity of crustal thickness in the study area was revealed by geophysical exploration (Gao and Ma, 1993; Cheng and Li, 1998). Such inhomogeneities in the Yanhuai basin lead to variations of migration velocity, absorption and occlusion effect of $\mathrm{Hg}$ vapor in its transition processes. Consequently, the results display that the background of $\mathrm{Hg}$ in soil gas in 


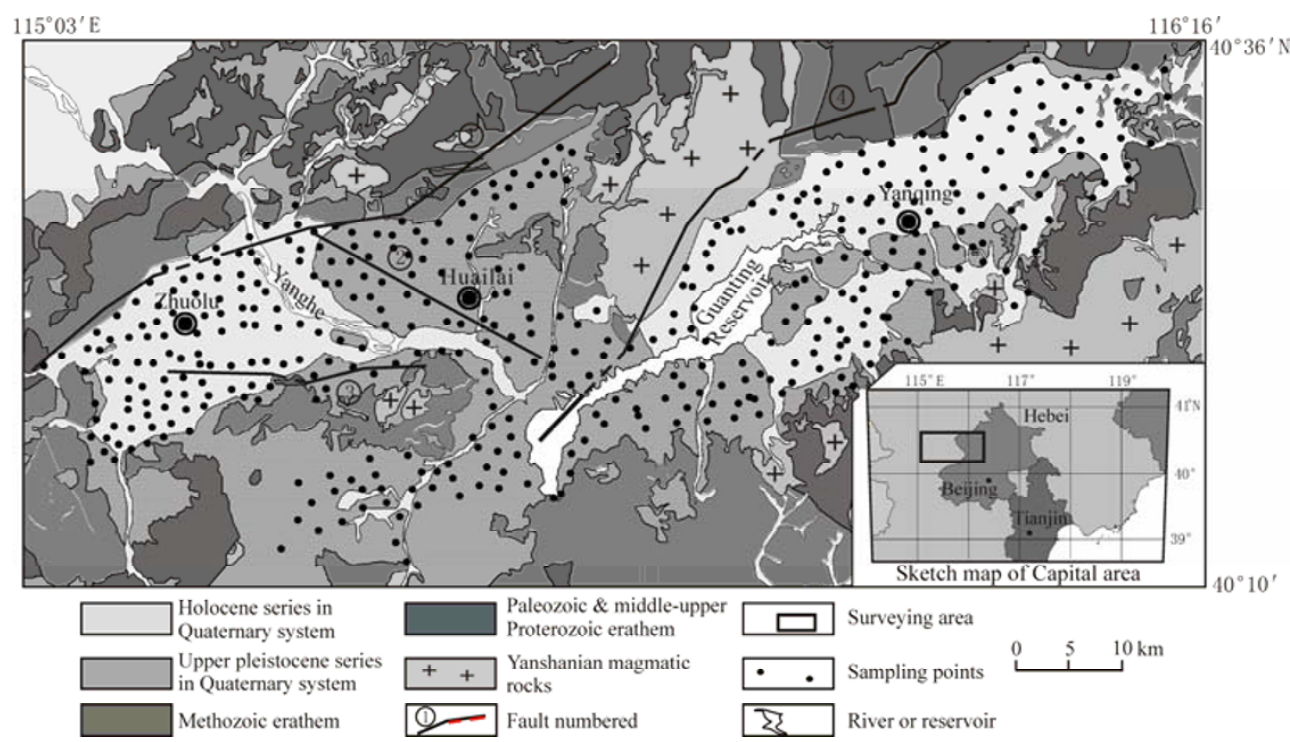

Figure 1 Generalized geology and surveying sites in the Yanhuai basin. (1) North boundary fault of Huaizhuo Basin; (2) Xinbaoan- Shacheng fault; (3) Sanggan river fault; (4) North boundary fault of Yanfan Basin, which is the borderline between Yanfan basin and Huaizhuo basin.

the Yanhuai basin is controlled by sources of $\mathrm{Hg}$, crustal structure, regional tectonics, strata, gas exchange between soil and atmosphere, etc.

Table 2 Factor analysis of soil gas data of the Yanhuai basin (rotated component matrix)

\begin{tabular}{crrcc}
\hline \multirow{2}{*}{ Gas species } & \multicolumn{5}{c}{ Factor } \\
\cline { 2 - 5 } & \multicolumn{1}{c}{1} & \multicolumn{1}{c}{2} & 3 & 4 \\
\hline $\mathrm{He}$ & 0.035 & 0.056 & 0.016 & 0.993 \\
$\mathrm{H}_{2}$ & 0.297 & 0.213 & 0.799 & -0.015 \\
$\mathrm{CH}_{4}$ & -0.356 & 0.779 & 0.046 & -0.035 \\
$\mathrm{CO}_{2}$ & 0.261 & 0.638 & 0.007 & 0.081 \\
$\mathrm{Rn}$ & 0.461 & 0.283 & -0.647 & -0.054 \\
$\mathrm{Hg}$ & 0.836 & -0.034 & 0.087 & 0.032 \\
\hline
\end{tabular}

\subsection{Methane}

$\mathrm{CH}_{4}$ is thought to be a reduced form of carbon and derived from a variety of sources. The major process involved in $\mathrm{CH}_{4}$ genesis is microbial action (Klusman, 1993). In an active tectonic area, methane has an increasing leak associated with heat release induced by the faults and fractures. Therefore, there is a correlation between the concentrations of releasing methane in soil gas and the activity of faults, indicating methane may be a good indicator for seismic activity in a fault active area (Toutain and Baubron, 1999). The measured average concentration of $\mathrm{CH}_{4}$ in soil gas in the Yanhuai ba$\sin$ is $12.7 \times 10^{-6}$, and the minimum and maximum concentrations are less than $0.1 \times 10^{-6}$ and $52.3 \times 10^{-6}$, respectively. Most sites with high values of $\mathrm{CH}_{4}$ concentrations detected scatter in the middle-eastern part of the
Yanhuai basin (Figure 2). On December 16, 1996, before the Shunyi $M_{\mathrm{S}} 4.5$ earthquake, ice in the Longqingxia reservoir cracked, and the storage water was disturbed intensively by bubbles.

Except a low content of $\mathrm{He}, \mathrm{CH}_{4}$ is the main component in the escaping gas discharged from the anomalous sits. The carbon isotope ratio of $\mathrm{CH}_{4}$ is $-51 \%$, which indicates that $\mathrm{CH}_{4}$ was mainly biogenic (GU et al, 2001). In the Yanhuai basin, the concentrations of $\mathrm{CH}_{4}$ and $\mathrm{CO}_{2}$ in soil gas are controlled by factor 2 (Table 2), which reflects that $\mathrm{CH}_{4}$ and $\mathrm{CO}_{2}$ may have a genetic correlation, i.e., $\mathrm{CO}_{2}$ can be formed through the oxidation of $\mathrm{CH}_{4}$. $\mathrm{Zu}$ et al (1997) confirmed that in the Yanhuai basin, the plain areas have a higher heat flow value than the mountain areas. Therefore, it is reasonable to conclude that the concentrations of the gaseous components are influenced in some degree by underground heat flows because both $\mathrm{CH}_{4}$ and $\mathrm{CO}_{2}$ concentrations are sensitive to heat flow value. In addition, there is a wide distribution of farmlands, rivers and reservoirs in the Yanhuai basin, providing a better environment for microbe action and organic matter deposit, which indicates geochemical backgrounds of $\mathrm{CH}_{4}$ and $\mathrm{CO}_{2}$ may be controlled by biogenic gases.

\subsection{Helium}

Helium is a product of the uranium-thorium decay series, which is thought to be a good tracer for active fault and indicator in earthquake monitoring and studying (Sugisaki, 1978; Du et al, 2008), because $\mathrm{He}$ is 

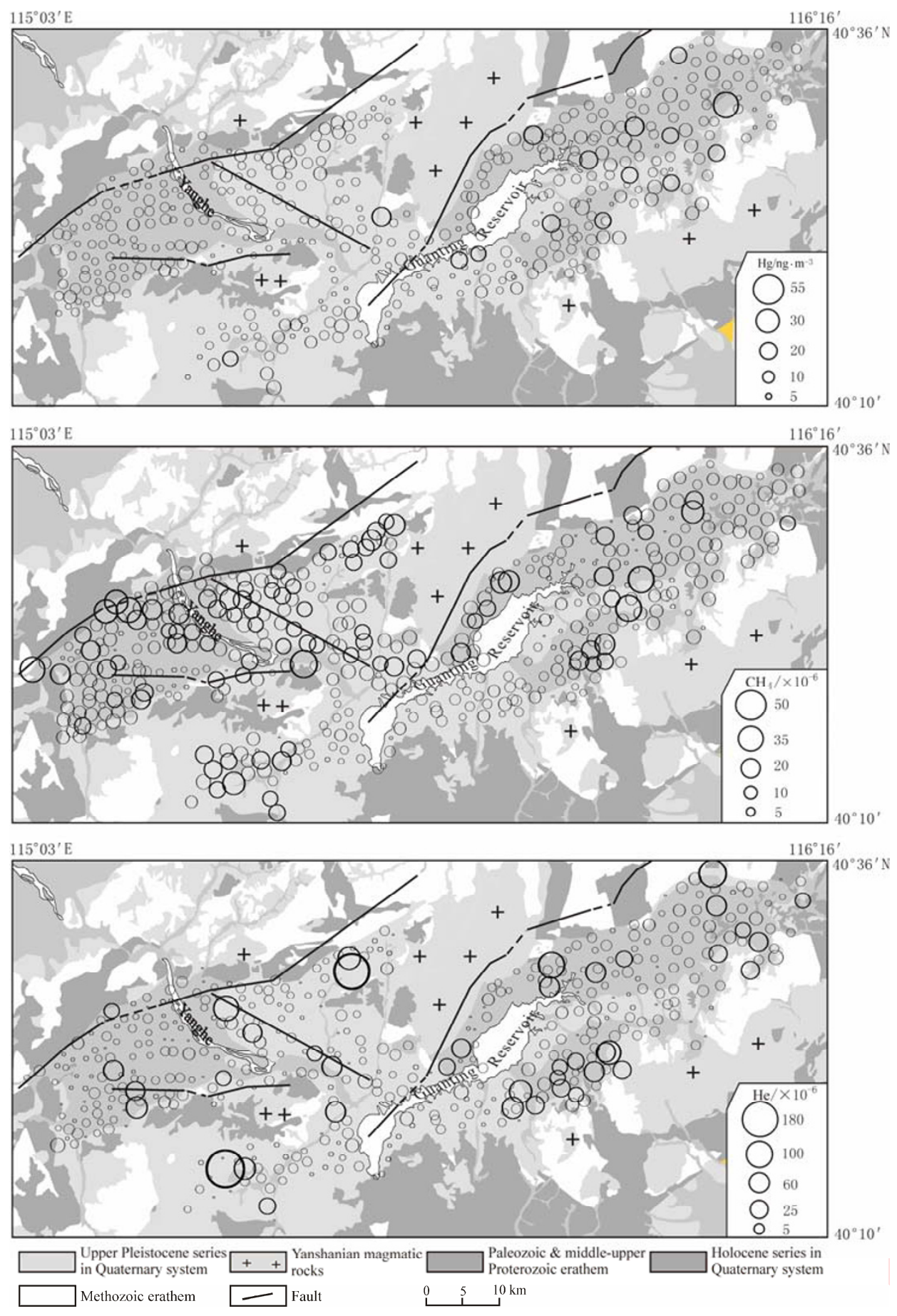

Figure 2 Map of concentrations of $\mathrm{Hg}, \mathrm{CH}_{4}$ and $\mathrm{He}$ in soil in the Yanhuai basin (For names of the faults see Figure 1).

chemically inert, physically stable, highly insoluble in water and highly mobile and able to pass through great thicknesses (150-800 m) of geological bodies (Ciotoli et al, 2005; 2007). In the Yanhuai basin, the average concentration of He in soil gas is $15.9 \times 10^{-6}$ which is 3 times of He concentration in air $\left(5.2 \times 10^{-6}\right.$, Holland and Emerson, 1990). The minimum and maximum concentra- tions are $0.1 \times 10^{-6}$ and $175.7 \times 10^{-6}$, respectively. The numbers of surveying sites with high concentration value $\left(\geq 40 \times 10^{-6}\right)$ and low concentration value $\left(\leq 5 \times 10^{-6}\right)$ account for $8 \%$ and $20 \%$, respectively. The He geochemical background value is higher in the eastern part of the Yanhuai basin than that in the western part (Figure 2), which may be induced by the largely granite 
distribution around the basin. After one week of Shunyi earthquake on December 16, 1996, He in the escaping gas from the Longqingxia reservoir is identified to be mainly originated from crust because the ${ }^{3} \mathrm{He} /{ }^{4} \mathrm{He}$ value in the gas is $2.6 \times 10^{-7}$ that is close to the value of crust (Gu et al, 2001). This conclusion is also supported by the isotopic geochemial data of the solution gas from the springs and/or wells in the Yanqing and Huailai regions (Wan et al, 2003). He derived from crust and mantle can dissipate in the air quickly after being transported up to ground surface. Geophysical research results in the Yanhuai basin reveal the existence of low velocity bodies at depth about $10 \mathrm{~km}$, and they interlace with low velocity bodies in the crust, as well as Tangshan region
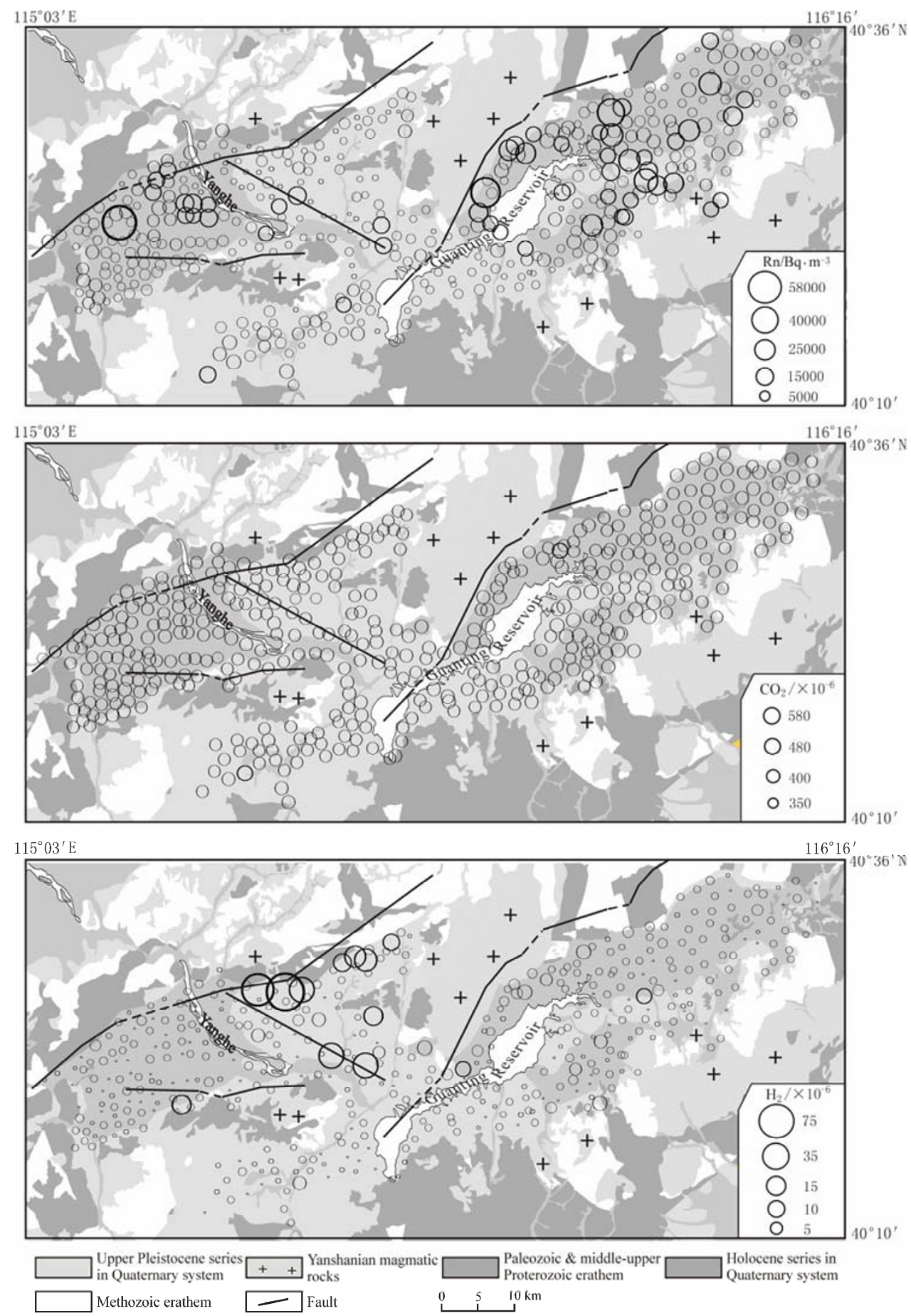

Figure 3 Map of $\mathrm{Rn}, \mathrm{CO}_{2}$ and $\mathrm{H}_{2}$ in soil gas of the Yanhuai basin (For names of the faults see Figure 1). 
(Liu et al, 2007). Therefore, the other factor controlling geochemical background character of helium is special inhomogeneity of fluids and rocks, as well as the supplying areas of thermal fluids from deep crust.

\subsection{Radon}

Activity of radon is known to be effectively controlled by temperature and pressure in the processes of absorption and desorption on the rock or/and soil grain surface, dissolution and transformation in underground water. Therefore, radon is sensitive and even escapes freely caused by the variation of underground stress field (Che et al, 2001). Radon concentrations are always alternative before an earthquake coming (Zhang et al, 1998; Igarashi et al, 1995; King et al, 1995; Steinitz et al, 2003). Thus it appears to be a powerful indicator for earthquake. In the Yanhuai basin, the average radon concentration in soil gas is $8105.8 \mathrm{~Bq} / \mathrm{m}^{3}$. There are five surveying sites where over high values $\left(\geq 30000 \mathrm{~Bq} / \mathrm{m}^{3}\right)$ of radon concentrations were detected scattering individually in the basin. Same as $\mathrm{Hg}$ and $\mathrm{He}$, the radon background value $\left(8831.85 \mathrm{~Bq} / \mathrm{m}^{3}\right)$ is higher in the eastern part of the basin than that in the eastern part $(8$ 105.80 $\mathrm{Bq} / \mathrm{m}^{3}$ ) due to the widely existence of granite (enriched in radioactive elements) in the eastern part of the basin. Furthermore, the factor analysis results (Table 2) show the factor 3 is contributed mostly by $\mathrm{H}_{2}$ and $\mathrm{Rn}$, but correlation between the concentrations of these two components is negative. On the other hand, He contributes to the factor 4 individually, which means that these 3 components have different sources or genesis. The sampling depth is $0.8 \mathrm{~m}$ and reaches the soil illuvial horizon of study area (Wang et al, 2006) where is in rich of radioactive elements $(\mathrm{U}, \mathrm{Th}$ and $\mathrm{Ra})$ that can generate $\mathrm{Rn}$ via radioactive decay. As a result, $\mathrm{Rn}$ in soil gas is derived mainly from the lower crust and $\mathrm{He}$ is from deeper source area (Du and Kang, 2000a).

\subsection{Carbon dioxide}

The presence of carbon dioxide in an active fault area may be resulted from (1) mantle degassing, (2) carbonate metamorphism and decomposition, (3) organic material oxidation and (4) microorganism or plant respiration (Sugisaki, 1983). High concentrations of carbon dioxide in soil gas are often related to high heat flux in an active volcanic area or the other areas cracked by deep faults (Ciotoli et al, 2007). $\mathrm{CO}_{2}$ discharges may serve as identifying fault activity and earthquake hazard (Irwin and Barnes, 1980; Annunziatellis et al, 2003). In the Yanhuai basin, the carbon dioxide concentrations range from $331.5 \times 10^{-6}$ to $572.6 \times 10^{-6}$ with a mean value of $395.9 \times 10^{-6}$. In the Velingrad area in Bulgaria, soil gas $\mathrm{CO}_{2}$ concentrations are in the range of $20000 \times 10^{-6}-60000 \times 10^{-6}$ (Toutain and Baubron, 1999). The average of $\mathrm{CO}_{2}$ concentration for 845 soil gas samples in the Fucino plain in central Italy is $33500 \times 10^{-6}$. $\mathrm{CO}_{2}$ concentrations for 106 soil gas samples from the Ofanto basin in southern Apennine mountains, Italy, are in a range from $1300 \times 10^{-6}$ to $155100 \times 10^{-6}$ (Ciotoli et al, 2007). In Pingdong area, Taiwan, crossed by Chaozhou fault, $\mathrm{CO}_{2}$ concentrations in soil gas range from 0 to $123100 \times 10^{-6}$ with mean content of $42100 \times 10^{-6}$ (Fu et al, 2005). Comparison between the $\mathrm{CO}_{2}$ concetrations in soil gas mentioned above and the results in the Yanhuai basin shows that the carbon dioxide in soil gas in the study area appears not to be oriented mainly from the deep earth. The average $\mathrm{CO}_{2}$ content of soil gas in the eastern part of the Yanhuai basin is $399.9 \times 10^{-6}$, close to the content of western part $\left(392.0 \times 10^{-6}\right)$, which reflects that there is little amount of $\mathrm{CO}_{2}$ from the deep earth, indicating a weaker tectonic activity in the Yanhuai basin.

\subsection{Hydrogen}

Hydrogen concentrations in soil gas vary in a large range (less than $0.1 \times 10^{-6}$ to dozens $\times 10^{-6}$ ) in fault zones where hydrogen is thought to be produced by the reactions between fractured rocks and groundwater. In detail, the reactions occur at fresh mineral interfaces when the fluids, such as groundwater, emerge into the space of rock fractures. A great deal of hydrogen is generated during such process and moves up to the surface through the fractures (Sugisaki, 1983; 1987). Therefore, $\mathrm{H}_{2}$ also is considered to be a good indicator for fault activity. In the study area, the minimum and maximum values of $\mathrm{H}_{2}$ concentrations in soil gas are $<0.1 \times 10^{-6}$ and $73.2 \times 10^{-6}$, respectively, and the average content is $4.0 \times 10^{-6}$. Five surveying sites with high $\mathrm{H}_{2}$ concentrations $\left(\geq 30 \times 10^{-6}\right.$ ), considered to be related to the active faults, distribute in the western part of the Yanhuai basin. Comparing with other areas of active faults in the world, the Yanhuai basin has a lower hydrogen concentration in soil gas, which may be induced by the reduce environment at the surveying soil depth. The Yanhuai basin is tectonically a dustpan basin with a deeper subsidence in northern-western edge. Factor analysis results (Table 2) show that $\mathrm{H}_{2}$ contributes to the factor 3 together with $\mathrm{Rn}$, but in negative correlation, which reflects that $\mathrm{H}_{2}$ is mainly derived from the deep Earth, but Rn mainly from the shallow crust. 


\subsection{Geochemical characteristics of soil gas in the Yanhuai basin}

The Huaizhuo basin and Yanfan basin are two sub-basins of the Yanhuai basin. The concentrations of $\mathrm{Rn}, \mathrm{Hg}, \mathrm{He}$ and $\mathrm{CO}_{2}$ are higher in the Yanfan basin, which indicates the fault activities are stronger there. Such a character is considered to be related to the thickness inhomogeneity of crust and the fault distribution in the basin. Artificial seismic sounding, magnetotelluric prospecting (Gao and Ma, 1993) and two dimensional temperature structure calculation ( $\mathrm{Zu}$ et al, 1997) demonstrate that the thickness of lithosphere and Moho depth increase gradually from east to west in the Yanhuai basin, resulting that $\mathrm{Rn}, \mathrm{Hg}, \mathrm{He}$ and $\mathrm{CO}_{2}$ are absorbed and dissolved in different degree when they penetrate the overlain strata in differential regions. Zhu et al (2006) predicted that the Yanfan basin appears to suffer more severe seismic hazards and a potential earthquake seams to occur earlier comparing to Huaizhuo basin according to the research on tectonics, fault slip velocity in the Yanhuai basin and magnitude-time prediction model calculation.

Except $\mathrm{CO}_{2}$, all the surveying gases have high concentration values that may be attributed to the sites located in the intersections of two or more fracture zones (Ciotoli et al, 1998; Fridman, 1990), and/or to the existence of special discontinuity around the sites leading an enrichment of the surveying component (Ciotoli et al, 1998; Lombardi et al, 1996). Consequently, it can be deduced that distributions of faults and fractures are more complicated than present known in the Yanhuai basin. However, this needs more work to be done in the future.

\section{Conclusions}

The geochemical backgrounds of six gases in soil in the Yanhuai basin are drawn out according to the measurements at 422 sampling sites. The geochemical backround values of $\mathrm{Rn}, \mathrm{Hg}, \mathrm{CO}_{2}, \mathrm{H}_{2}, \mathrm{He}$ and $\mathrm{CH}_{4}$ are $(8105.8 \pm 5937.4) \mathrm{Bq} / \mathrm{m}^{3},(9.7 \pm 5.8) \mathrm{ng} / \mathrm{m}^{3},(395.9 \pm 35.3) \times$ $10^{-6},(4.0 \pm 2.3) \times 10^{-6},(15.9 \pm 10.4) \times 10^{-6}$ and $(12.7 \pm 8.1) \times$ $10^{-6}$, respectively, and $\mathrm{Rn}, \mathrm{Hg}, \mathrm{He}$ and $\mathrm{CO}_{2}$ show higher background values in the eastern part of the Yanhuai basin.

The factor analysis on the soil gas data and the geological characteristics indicate that the concentrations of the six studied gases are derived from various sources and affected by different factors in the Yanhuai basin. Rn in soil gas is mainly derived from the sources in the upper crust correlating with the petrological geochemistry character in the area. $\mathrm{Hg}$ and He are mostly from deep sources involving the inhomogeneity of local crust. On the contrary, $\mathrm{CO}_{2}$ and $\mathrm{CH}_{4}$ are mostly derived from the upper crust, and dominated by underground heat flow and biogenic action. $\mathrm{H}_{2}$ has mainly a deep crust origin and affected by the redox environment in soil illuvial horizon. We therefore conclude that in the Yanhuai basin, the soil gas geochemical background is correlated to the regional characteristics of seismogeology and can be used to study the tendency of earthquake activity.

Acknowledgements This study is supported by Science Fund of Institute of Earthquake Science, China Earthquake Administration (02076902-32); Joint Seismological Science Foundation of China (B07002); National Natural Science Foundation of China (40703013).

\section{References}

Annunziatellis A, Ciotoli G, Lombardi S and Nolasco F (2003). Short and long term gas hazard: The release of toxic gases in the Alban Hills volcanic area (Italy). J Geochem Explor 77: 93-108.

Baubron J C, Rigo A and Toutain J P (2002). Soil gas profiles as a tool to characterize active tectonic areas: The Jaut Pass example (Pyrenees, France). Earth Planet Sci Lett 196: 69-81.

Cao Z C (2005). Seismic Monitoring Log of Hebei Province in China. Seismological Press, Beijing, 1-356 (in Chinese).

Che Y T, Wang J H, Yu J Z, Liu W Z and Song G Y (2001). Character of thermal fluids in upper crust and relationship with seismicity in Yanqing-Huailai Basin. Seismology and Geology 23(1): 49-54 (in Chinese with English abstract).

Che Y T (2002). Digital Techniques Monitoring Underground Fluids. Seismological Press, Beijing, 1-120 (in Chinese).

Cheng J and Li Q H (1998). Study on fine structure of crust-mantle transition zone in Yanhuai basin based on CDP and DSS data. Acta Seismologica Sinica 20(1): 68-75 (in Chinese with English abstract).

Chiodini G, Cardellini C, Amato A, Boschi E, Caliro S, Frondini F and Ventura G (2004). Carbon dioxide Earth degassing and seismogenesis in central and southern Italy. Geophys Res Lett 31, L07615, doi: 10.1029 /2004GL019480.

Ciotoli G, Guerra M, Lombardi S and Vittori E (1998). Soil gas survey for tracing seismogenic faults: A case study in the Fucino Basin, central Italy. J Geophys Res 103: 23 781-23 794.

Ciotoli G, Lombardi S and Annunziatellis A (2007). Geostatistical analysis of soil gas data in a high seismic intermontane basin: Fucino Plain, central Italy. J Geophys Res 112, B05407, doi: 10.1029/2005JB004044.

Ciotoli G, Lombardi S, Morandi S and Zarlenga F (2005). A multidisciplinary statistical approach to study the relationships between helium leakage and neo-tectonic activity in a gas province: The Vasto Basin, Abruzzo-Molise (central Italy). AAPG Bull 88(3): 355-372.

Du J G, Si X Y, Chen Y X, Fu H, Jian C L and Guo W S (2008). Geochemical anomalies connected with great earthquakes in China. In: Ó Stefánsson ed Geochemistry Research Advances, Nova Science Publishers Inc, New York, 57-92.

Du J G and Kang C L (2000a). A brief review on study of earthquake-caused change of underground fluid. Earthquake 20 (Suppl): 107-113 (in Chinese with English abstract). 
Du J G. and Kang C L (2000b). Characteristics of earthquake precursors and its geological significance. Earthquake 20(3): 95-101 (in Chinese with English abstract).

Du J G, Liu L Z and Kang C L (1997). The role of deep-crust fluids in earthquake activity. Advances in Earth Science 12(5): 416-420 (in Chinese with English abstract).

Du L T (2005). Significance of earth degassing and its research progress. Geological Review 51(2): 174-180 (in Chinese with English abstract).

Fridman A I (1990). Application of naturally occurring gases as geochemical pathfinders in prospecting for endogenetic deposits. J Geochem Explor 38: $1-11$.

Fu C C, Yang Tsanyaofrank, Walia Vivek and Chen C H (2005). Reconnaissance of soil gas composition over the buried fault and fracture zone in southern Taiwan. Geochem J 39: 427-439.

Gao W X and Ma J (1993). Seismo-geological Background and Earthquake Hazard in the Capital Area. Seismological Press, Beijing, 1-249 (in Chinese).

Gu Y Z, Lin Y W and Zhang P R (2001). Application of gas geochemical method to prediction of seismic trend after main shock. Earthquake 21(2): 102-105 (in Chinese with English abstract).

Holland P W and Emerson D E (1990). The global helium-4 content of near-surface atmospheric air. In: Durrance E M, Galimov E M, Hinkle-margaret E, Reimer G M, Sugisaki-Ryuichi, Augustithis S S eds. Geochemistry of Gaseous Elements and Compounds. Theophrastus, Athens, 93-113.

Igarashi G, Sacki S, Takahata N, Sumikawa K, Tasaka S, Sasaki Y, Takahashi M andSano Y (1995). Groundwater radon anomaly before the Kobe earthquake in Japan. Science 269: 60-61.

Igarashi G and Wakita H (1995). Geochemical and hydrological observations for earthquake prediction in Japan. J Phys Earth 43: 585-598.

Irwin W P and Barnes I (1980). Tectonic relation of carbon dioxide discharges and earthquakes. J Geophys Res 85: 3 115-3 121.

King C Y, Koizumi and Kitagawa Y (1995). Hydrogeochemical anomalies and the 1995 Kobe earthquake. Science 269: 38-39.

Klussman R W (1993). Soil Gas and Related Methods for Natural Resource Exploration. John Wiley, New York.

Liu C Q, Jia S X, Liu M J and Li C F (1997). Analysis and study of the large earthquake risk in Yanqing-Huailai basin. Acta Seismologica Sinica 19(5): 517-523 (in Chinese with English abstract).

Liu Q Y, Wang J, Chen J H, Li S C and Guo B (2007). Seismogenic tectonic environment of 1976 great Tangshan earthquake: results given by dense seismic array observations. Earth Science Frontiers 14(6): 205-213 (in Chinese with English abstract).

Liu Y W, Chen H J and Che Y T (2006). Retrospect and prospect of observation and study on seismic underground fluid in China. Recent Developments in World Seismology (7): 3-12 (in Chinese).

Lombardi S, Etiope G, Guerra M, Ciotoli G, Grainger P, Duddridge G A, Gera F, Chiantore V, Pensieri R, Grindrod P and Impey M (1996). The refinement of soil gas analysis as a geological investigative technique. In: The 4th CEC R\&D Programme on Management and Storage of Radioactive Waste
(1990-1994), Final Report. Nucl. Sci. Technol. Ser., Brussels: Eur. Comm. Steinitz G Z B, Begin and Gazit-Yari N (2003). Statistically significant relation between radon flux and weak earthquakes in the Dead Sea rift valley. Geology 31(6): 505-508.

Sugisaki R (1978). Changing He/Ar and $\mathrm{N}_{2} / \mathrm{Ar}$ ratios of fault air may be earthquake precursors. Nature 275: 209-211.

Sugisaki R (1983). Origin of hydrogen and carbon dioxide in fault gases and its relation to fault activity. $J$ Geol 91: 239-258.

Sugisaki R (1987). Behavior and origin of helium, neon, argon and nitrogen from active faults. $J$ Geophys Res 92: 12 523-12 530.

Toutain J P and Baubron J C (1999). Gas geochemistry and seismotectonics: A review. Tectonophysics 304: 1-27.

Wan Y G., Wu Z L, Zhou G W, Huang J and Qin L X (2002). Research on seismic stress trigging. Acta Seismologica Sinica 21(5): 533-551 (in Chinese with English abstract).

Wang C M (1990). China Earthquake Observation System of Underground Water. Seismological Press, Beijing, 5-50 (in Chinese).

Wang G C, Zhang Z C, Wang M, Wang J H, Liu W Z, Yi L X and Sun M L (2003). Geochemistry of geothermal water and noble gases in Yanhuai basin, China. Seismology and Geology 25(3): 422-430 (in Chinese with English abstract).

Wang X Y, Zhu L, Lv L, Wang Z L and Fan G (2006). Introduction of Soil-Gas Radon in China. Science Press, Beijing, 1-277 (in Chinese).

Wei J Z and Shen C S (1995). The application of mercurometric survey to earthquake prediction: An analysis of case studies. Geophysical \& Geochemical Exploration 18(3): 216-222.

Xu P (2006). Seismic Monitoring Log of Beijing District in China. Seismological Press, Beijing, 1-200 (in Chinese).

Xu X W, Wu W M, Zhang X K, Ma S L, Ma W T, Yu G H, Gu M L and Jiang W L (2002). Recent Tectonic Activity and Earthquake in the Capital Area. Science Press, Beijing (in Chinese).

Zhang W, Wang J Y and Er X M (1988). Hydrological and Geochemical Principles and Methods of Earthquake Prediction. Educational Science Publishing House, Beijing, 1-376 (in Chinese).

Zhang W, Xing Y A and Wang J Y (1990). Discussion on hydrogeochemical indicators of monitoring and predicting earthquake. In: Corpus of Applied Methods Predicting and Researching Earthquake. Seismological Press, Beijing, 289-299 (in Chinese).

Zhang X and Sanderson D J (1996). Numerical modeling of the effects of fault slip on fluid flow around extensional faults. J Struct Geol 18: 109-119.

Zhou X C, Du J G., Wang C Y, Cao Z Q, Yi L and Liu L (2007). Geochemical characteristics of radon and mercury in soil gas in Lhasa, Tibet, China. Environmental Science 28(3): 659-663.

Zhu H S, Zhao C M, Li G. H, Xue Z F and Jiang W (2006). Tectonic characterristics of Yanhuai basin and evaluation of potential seismic risk. North China Earthquake Science 24(1): 38-42 (in Chinese with English abstract).

Zu J H, Wu Q F and Lian Y F (1997). A research on the geothermal structure in Yanqing-Huailai Basin and its neighbouring region. Acta Seismologica Sinica 19(4): 442-444 (in Chinese with English abstract). 